\title{
Ethnomedicinal Herbs Used in Oral Health and Hygiene in Coastal Dakshina Kannada
}

\author{
Maji Jose ${ }^{1}$, Bhagya B ${ }^{2}$, Manjula Shantaram ${ }^{3}$
}

\begin{abstract}
Objectives: The present study was conducted to document the ethnomedicinal practices followed for oral health and diseases by people of Dakshina Kannada (DK) district, and to suggest that the traditional knowledge should be integrated with modern dental care practices to formulate their sustainable utilization.

Methods: An ethnomedicinal survey was conducted using specific questionnaire subsequent to personal interview to collect information from traditional healers, local inhabitants, ayurvedic practitioners and botanists on the use of medicinal plants in oral care practices.

Results: This study identified 32 species belonging to 29 genera and 20 families, commonly used by the people of DK region to maintain oral health and hygiene and as remedy for dental diseases.

Conclusion: Valuable ethnomedicinal practices are fast disappearing from rural population. New generation is ignorant of this traditional knowledge. So measures should be taken to document them and to increase the awareness among youngsters. This study will also be useful for the pharmacologists to isolate the active principles of these plants and incorporate it into the modern healthcare practices for easier and cheaper oral health treatments.
\end{abstract}

Keywords: Medicinal plants, Traditional knowledge, Oral hygiene, Oral diseases, Dakshina Kannada

${ }^{1}$ Professor of Oral Pathology,

Yenepoya Dental College,

Yenepoya University,

Mangalore, Karnataka, India

${ }^{2}$ Lecturer of Genetics,

Department of Anatomy,

Yenepoya Medical College,

Yenepoya University,

Mangalore, Karnataka, India

${ }^{3}$ Associate Professor of Biochemistry,

Yenepoya Medical College,

Yenepoya University,

Mangalore, Karnataka, India

\section{Contact Author}

Dr. Manjula Shantaram

manjula59@gmail.com

J Oral Health Comm Dent 2011;5(3)119-123

\section{INTRODUCTION}

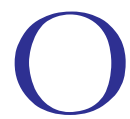

ral hygiene is an integral part of

health of a person. Oral health when neglected, results in different types of oral ailments like dental caries and periodontal diseases. Oral disorders can significantly affect the general well-being of a person by causing considerable pain and discomfort, thus affecting their quality of life. Dental caries and periodontal diseases are the two common threats to oral health and are important public health problems because of their prevalence, their impact on individuals and society, and the expense of their treatment (1). Oral diseases are caused due to bacterial infections, food habits and life style.

The rich plant diversity of India is utilized by the native communities in various forms of medicine. Medicinal plants have been used for thousands of years in folk medicine for maintaining oral hygiene. Most of these herbs are alkaline with high antibacterial activity. Hence these herbs help to maintain acid-alkaline balance of the saliva, decrease plaque/calculus formation and are less prone to periodontal diseases. It is also observed that the microorganisms found in inflamed gums are resistant to antibiotics but not to antibacterial plant extracts like neem. And unlike antibiotics, antibacterial plant extracts produced no allergy in the gingiva. One of the common traditional practices followed is use of herbal 'chewing sticks' instead of plasticbristle brushes to maintain oral health and hygiene. The best known examples of traditional chewing sticks used are neem and meswak (2), the end of which is shredded and then used to massage the gums and clean the teeth. Various studies have shown that rural folk in different parts of Karnataka use stem, leaves and fibers of some plants for cleaning teeth, preventing and treating dental caries, gingival and periodontal diseases and other oral mucosal diseases.

Dakshina Kannada district of Karnataka, with a $60 \mathrm{~km}$ long coastline $\left(12^{\circ} 572 \mathrm{~N}, 70^{\circ}\right.$ $\left.492 \mathrm{E}-14^{\circ} 512 \mathrm{~N}, 74^{\circ} 72 \mathrm{E}\right)$ has a total land area of $4770 \mathrm{sq}$. km. It receives good 
rainfall between June and September and has total area of 1,28,476 hectares forest which is an excellent treasure of medicinal plants (3). The rapidly vanishing awareness about traditional methods used for routine oral hygiene practices and herbal remedies for various dental diseases demand an urgent need to document this invaluable indigenous knowledge. The purpose of the study was to explore and document indigenous uses of medicinal plants in various oral hygiene practices and local remedies used traditionally in treating oral diseases by the people of Dakshina Kannada district.

\section{MATERIALS AND METHODS}

An ethnomedicinal survey was conducted between 2008-2009 to collect information on the medicinal plants which has been used traditionally for oral health and hygiene. About 70 local people, 4 traditional healers, 5 folk practitioners, 4 botanists and 20 elderly people were interviewed for the purpose of documentation of various medicinal plants used in oral health and against tooth and gum disorders. The ethnomedicinal investigation was done systematically using a specific questionnaire (Table 1). Interview was carried out in local language. One questionnaire was used for recording single use of a single species by a single respondent. In addition to general details on the plant parts used, the purpose for which it is used such as routine teeth cleaning, tooth decay, gum diseases, oral mucosal diseases such as stomatitis or oral aphthous ulcers were noted down. The preparations of herbal formulations, their mode of administration were also recorded. The plants documented are arranged alphabetically of their scientific names along with family followed by local name, parts used, medicinal use and mode of preparation and administration (Table 2).

\section{RESULTS}

Present study includes information on 32 species belonging to 29 genera and 20 families, traditionally being used for oral health and hygiene by local inhabitants of Dakshina Kannada (Figs. 1-6) Out of the 32 species 11 species were used for routine oral hygiene practices (Table 3). Tender twigs of 6 species were used as 'chewing sticks'. One end of the chewing stick is chewed and shredded, which was then used to clean the teeth and massage the gums. Leaves of 3 species of plants were used for cleaning the teeth. The leaves were rolled and one end of the roll was chewed to make it soft and fibrous and used for cleaning. Alternatively whole leaves were chewed to make an infusion of the leaf extract with saliva. This mixture along with fibrous leaf material was rubbed against teeth and gum using finger for cleansing. Some locals mentioned the use of fibrous pericarp of coconut and arecanut for cleaning teeth.

Twenty five plants were mentioned by the local inhabitants as being used in treating various oral diseases. Ten species were used for tooth decay, 5 in treating gum disease and 10 for stomatitis or oral ulcers. The various parts of plants used, other ingredients used in the preparation and mode of administration are discussed in Table 2. Leaves of Abrus precatorius, Acacia arabica, Basella alba, Bridelia scandens, Cassia alata, Cassia tora, Erythrina indica, Jatropha curcus, Lawsonia alba, Mangifera indica, Piper beetle, and Psidium gujava are chewed, extract applied or decoction used in treating oral ailments. Seeds of Acacia catechu and Areca catechu are eaten along with beetle leaves, cardamom, clove etc which has a synergistic effect in reducing bacterial load in oral cavity. Extracts or powders of fruits of Ficus bengalensis, Momordica charantia and Terminalia chebula are used in treating toothache and aphthous ulcers. Latex of Calotropis gigantea and Jatropha gossypifolia is applied into the aching tooth to relieve pain. Decoction of the bark of Acacia arabica, Tamarindus indica, and Tectona grandis is used in curing aphthous ulcer. Chewing of the flower buds of Spilanthes paniculata, Myrtus caryophyllus and decoction of Cassia alata flowers helps to relieve pain caused by tooth ache. Juice of young branches of Indigofera tinctoria and young stem of Jatropha curcus is used as tooth brush which heals bleeding gums and gum boils. Fresh juice of the roots of Moringa oleifera is used in treating dental caries.

In addition other traditional practices such as using charcoal, burnt rice bran mixed with salt, soot formed on the vessels or chimneys by burning wood are routinely
Table 1: Questionnaire used for Ethnomedicinal survey of herbs used in oral health and diseases

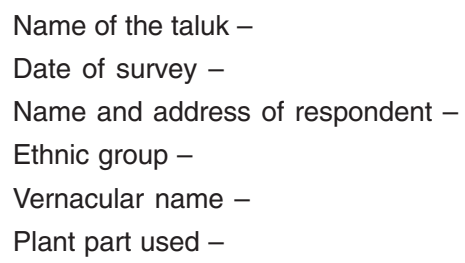

\begin{tabular}{|c|c|c|c|c|c|}
\hline Plant part & $\begin{array}{l}\text { Routine } \\
\text { cleaning of } \\
\text { teeth }\end{array}$ & $\begin{array}{l}\text { Tooth } \\
\text { decay }\end{array}$ & $\begin{array}{c}\text { Gum } \\
\text { diseases }\end{array}$ & Stomatitis & $\begin{array}{l}\text { Oral } \\
\text { ulcers }\end{array}$ \\
\hline \multicolumn{6}{|l|}{ Root } \\
\hline \multicolumn{6}{|l|}{ Stem } \\
\hline \multicolumn{6}{|l|}{ Leaf } \\
\hline \multicolumn{6}{|l|}{ Flower } \\
\hline \multicolumn{6}{|l|}{ Fruit } \\
\hline \multicolumn{6}{|l|}{ Seed } \\
\hline \multicolumn{6}{|l|}{ Other parts } \\
\hline $\begin{array}{l}\text { Preparation } \\
\text { Method of } p \\
\text { Mode of adn } \\
\text { Any other cc }\end{array}$ & $\begin{array}{l}\text { sed - Poultice } \\
\text { eparation - } \\
\text { nistration - } \\
\text { nment - }\end{array}$ & coction/ & & & \\
\hline
\end{tabular}


Table 2: Herbs used as remedy for various oral health problems

\begin{tabular}{|c|c|c|c|c|c|}
\hline Taxon & Family & Local name & Part used & Medicinal use & Mode of use \\
\hline Abrus precatorius $\mathrm{L}$ & Papilionaceae & Gulagangi & leaves & Aphthous stomatitis & $\begin{array}{l}\text { Juice of the tender leaves is swallowed } \\
\text { by chewing them }\end{array}$ \\
\hline Acacia arabica Willd & Mimosaceae & Karijali & $\begin{array}{l}\text { Tender leaves } \\
\text { Bark }\end{array}$ & $\begin{array}{l}\text { Spongy gums, } \\
\text { Sore-throat, } \\
\text { Aphthous stomatitis, } \\
\text { cancerous lesions }\end{array}$ & $\begin{array}{l}\text { Decoction of the tender leaves } \\
\text { is used as gargle } \\
\text { Decoction is used as a gargle } \\
\text { and mouth wash } \\
\text { Burnt bark along with other components is } \\
\text { used as tooth powder }\end{array}$ \\
\hline Acacia catechu Willd & Mimosaceae & Khadira & Bark & Tooth ache & $\begin{array}{l}\text { A piece of bark is placed in the cavity of } \\
\text { aching tooth }\end{array}$ \\
\hline Areca catechu $\mathrm{L}$ & Palmae & Adike & Seed & Prevents tooth decay & $\begin{array}{l}\text { Chewed along with lime, betel leaf and } \\
\text { tobacco. }\end{array}$ \\
\hline Basella alba L & Basellaceae & Basale soppu & leaves & Aphthous ulcer & $\begin{array}{l}\text { Tender leaves are washed and chewed. } \\
\text { The extract of the leaf is retained in the } \\
\text { mouth for some time. }\end{array}$ \\
\hline $\begin{array}{l}\text { Bridelia scandens (Roxb.) } \\
\text { Willd }\end{array}$ & Euphorbiaceae & Gurige & leaves & Tooth decay and pain & $\begin{array}{l}\text { Leaves are boiled in water with a pinch of } \\
\text { salt and the steam is inhaled into mouth }\end{array}$ \\
\hline $\begin{array}{l}\text { Calotropis gigantea } \\
\text { (L.) R. Br. }\end{array}$ & Asclepiadaceae & Yekkada gida & Latex & $\begin{array}{l}\text { Aphthous stomatitis } \\
\text { Tooth ache }\end{array}$ & $\begin{array}{l}\text { Latex is mixed with honey and applied } \\
\text { Latex is inserted into the carious tooth }\end{array}$ \\
\hline Carica papaya $\mathrm{L}$ & Caricaceae & Parangi hannu & Juice/pulp & $\begin{array}{l}\text { Ulcers and fissures of } \\
\text { the tongue }\end{array}$ & $\begin{array}{l}\text { Juice/ pulp should be applied on affected } \\
\text { area }\end{array}$ \\
\hline Cassia alata $\mathrm{L}$ & Caesalpiniaceae & Aane thagathe & $\begin{array}{l}\text { Leaves and } \\
\text { flowers }\end{array}$ & Stomatitis & $\begin{array}{l}\text { Decoction of leaves and flowers is used } \\
\text { as mouth wash }\end{array}$ \\
\hline Cassia tora L & Caesalpiniaceae & Tagathe & Leaves & $\begin{array}{l}\text { Teething problems } \\
\text { in children }\end{array}$ & Decoction of leaves is used as gargle \\
\hline Erythrina varaegita L. var. & Papilionaceae & Hongaarae & Leaves & Tooth ache & Leaf extract is applied into aching tooth. \\
\hline Ficus bengalensis $\mathrm{L}$ & Moraceae & Aalada mara & $\begin{array}{l}\text { Latex } \\
\text { Slender twigs }\end{array}$ & $\begin{array}{l}\text { Tooth ache } \\
\text { Strengthens gums } \\
\text { and teeth }\end{array}$ & $\begin{array}{l}\text { Latex to be applied on teeth and gums. } \\
\text { Slender twigs used as tooth brush }\end{array}$ \\
\hline Indigofera tinctoria $\mathrm{L}$ & Papilionaceae & Neeli & Young branches & Aphthous ulcers & $\begin{array}{l}\text { Extract of young branches mixed with } \\
\text { honey and applied }\end{array}$ \\
\hline Jatropha curcas $\mathrm{L}$ & Euphorbiaceae & Dodda-haralu & $\begin{array}{l}\text { Fresh stem } \\
\text { Leaves }\end{array}$ & $\begin{array}{l}\text { To strengthen gums, } \\
\text { curebleeding gums, boils }\end{array}$ & $\begin{array}{l}\text { Fresh stem is used as tooth brush } \\
\text { Decoction of leaves used as gargle }\end{array}$ \\
\hline Jatropha gossypifolia L & Euphorbiaceae & Bettada-haralu & Latex & Tooth ache & $\begin{array}{l}\text { Latex applied into the cavity of aching } \\
\text { tooth }\end{array}$ \\
\hline Lawsonia inermis L & Lythraceae & Madarangi & Leaves & Ulcers of mouth & Decoction of leaves is used as gargle \\
\hline Mangifera indica $\mathrm{L}$ & Anacardiaceae & Mavinamara & Leaves & Sensitivity of teeth & Tender leaves are chewed \\
\hline Momordica charantia $\mathrm{L}$ & Cucurbitaceae & Hagala kayi & Fruit & Aphthae & Extract of fruit pulp is used on aphthae \\
\hline Moringa oleifera Lam & Moringaceae & Nugge & Root bark & Dental caries & $\begin{array}{l}\text { Fresh juice of theroot bark is applied to } \\
\text { the cavity of tooth }\end{array}$ \\
\hline Piper betle L & Piperaceae & Vilayadelay & Leaves & Bad breath & $\begin{array}{l}\text { Leaves are chewed along with other } \\
\text { ingredients which are used for betel quid }\end{array}$ \\
\hline Psidium guajava $\mathrm{L}$ & Myrtaceae & Perale & Leaves & $\begin{array}{l}\text { Swollen gums and } \\
\text { mouth ulcers }\end{array}$ & Decoction of leaves are applied locally \\
\hline $\begin{array}{l}\text { Spilanthes paniculata } \\
\text { Wall. ex DC. }\end{array}$ & Asteraceae & Vana mugali & Flower heads & Tooth ache & Flower heads are chewed \\
\hline $\begin{array}{l}\text { Syzygium aromaticum (L.) } \\
\text { Merr. \& Perry }\end{array}$ & Myrtaceae & Lavanga & Flower buds & $\begin{array}{l}\text { Bad breath, dry mouth, } \\
\text { tooth ache }\end{array}$ & $\begin{array}{l}\text { Flower bud should be chewed } \\
\text { and then stuffed in to the cavity }\end{array}$ \\
\hline Tamarindus indica $\mathrm{L}$ & Caesalpiniaceae & Hunase hannu & Fruit & $\begin{array}{l}\text { Aphthous sores, } \\
\text { sore throats }\end{array}$ & Gargle of tamarind water is used \\
\hline Tectona grandis L. f. & Verbenaceae & Saaguvaani mara & Wood & Tooth ache & $\begin{array}{l}\text { A piece of wood is bruised water and } \\
\text { applied into aching tooth }\end{array}$ \\
\hline Terminalia chebula Retz. & Combretaceae & Anilaykayi & Fruits & Aphthous ulcer & $\begin{array}{l}\text { Thick paste is mixed with ghee and } \\
\text { applied on ulcers }\end{array}$ \\
\hline
\end{tabular}




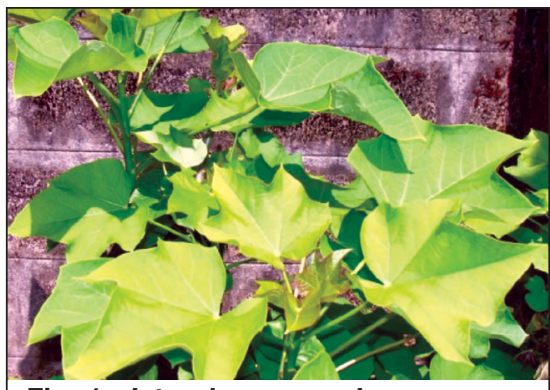

Fig. 1: Jatropha curcus $\mathrm{L}$

used for regular cleaning of teeth. Local application of clove oil into the cavity of aching tooth to relieve pain, application of honey or ghee on to oral ulcers are also common practices.

\section{DISCUSSION}

The present study provides information on various traditional oral hygiene practices and herbs used for oral health and diseases. Ethnomedicinal knowledge has been builtup due to untiring efforts and personal experimentation of our ancestors. These time-tested remedies have to be documented and preserved for sustainable utilization(4).

The traditional healers are of the opinion that medicinal herbs are very effective in treating some of the oral diseases such as

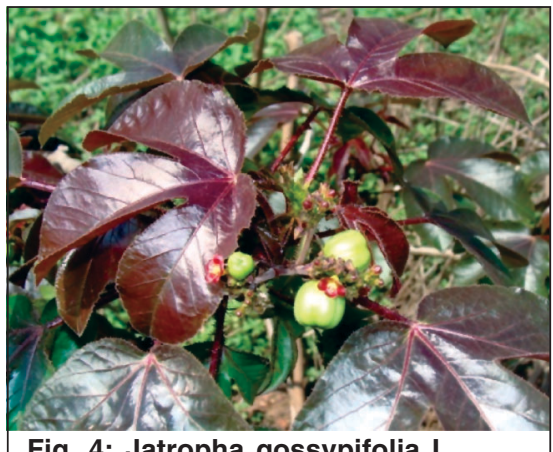

Fig. 4: Jatropha gossypifolia L

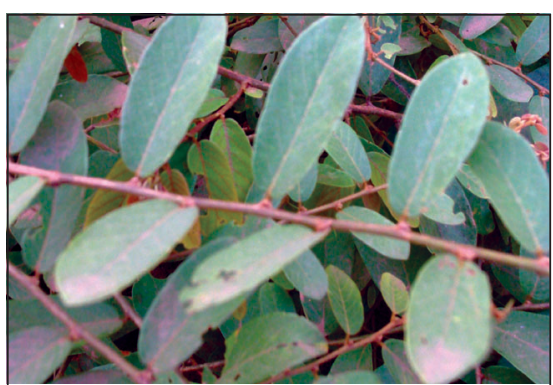

Fig. 6: Bridelia scandens (Roxb.) Willd

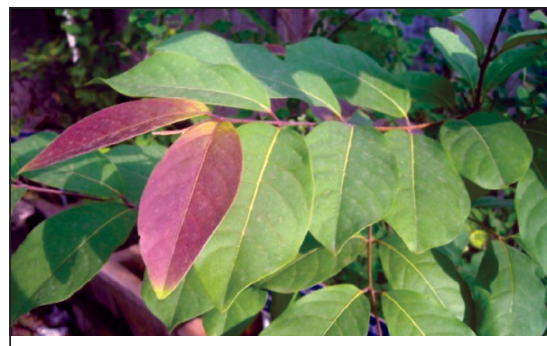

Fig. 2: Terminalia chebula Retz

aphthous ulcer, which do not have a specific treatment in modern medicine. Although dental caries and periodontal diseases require intervention by dental professionals for permanent cure, the information obtained in the survey disclosed that some of the herbal remedies are highly competent in relieving the associated pain and swelling.

Herbs such as Melia azadirachta, Moringa pterygosperma and Balsamodendron mukul are commonly being used in prevention of dental caries (5). Hebber et al (6) reported 35 plants belonging to 26 families used to treat different oral ailments like toothache, caries, periodontal diseases and aphthae by the people of Western Ghat region of Dharwad district of Karnataka. Jatropha

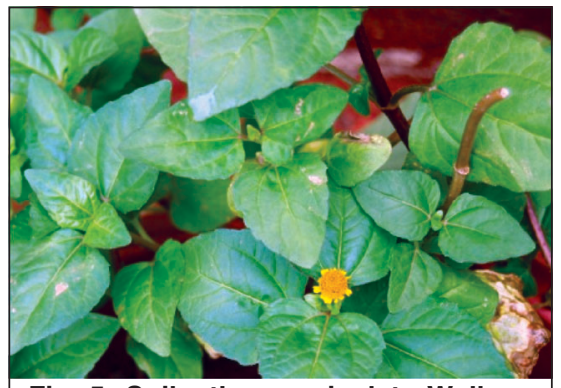

Fig. 5: Spilanthes paniculata Wall. ex DC

\section{Table 3: Herbs used for routine cleaning of teeth}

\begin{tabular}{|llll|}
\hline Taxon & Family & Local name & Part used \\
\hline Achyranthes aspera L & Amaranthaceae & Uttaranee & Root \\
Anacardium occidentale L & Anacardiaceae & Gaerumara & Twigs, Leaves \\
Areca catechu L & Palmae & Adike & Pericarp \\
Azadirachta indica A. Juss. & Meliaceae & Kahibevu & Twigs \\
Citrus limonum Risso & Rutaceae & Nimbehannu & Outer peel \\
Cocos nucifera L & Palmae & Thenginamara & Husk \\
Ficus bengalensis L & Urticaceae & Aladamara & Slender twigs \\
Jatropha curcas L & Euphorbiaceae & Kadaharalu & Twigs \\
Jatropha gossypifolia L & Euphorbiaceae & Bettadaharalu & Twigs \\
Mangifera indica L & Anacardiaceae & Mavina mara & Twigs \& leaves \\
Pongamia pinnata L., Pierre & Papilionaceae & Hongemara & Leaves \\
\hline
\end{tabular}


medicinal plants are due to the presence of potential bioactive compounds which help to reduce bacterial load in the oral cavity and thus prevent formation of plaque, dental caries and ulcers. Use of indigenous plants in oral health and hygiene has a long history in different parts of the world. However, this knowledge is likely to vanish soon as many of these ethnophytotherapeutic remedies are followed only by a few in rural areas. New generation is ignorant of this traditional knowledge. Younger generation lack knowledge on the identification, collection, preservation and processing of the plant species for medicinal use. Therefore it is crucial to conserve these ethnocultural practices before they are lost definitively. Proper documentation of these ethnomedicinal practices helps to avoid biopiracy and also to conserve the rich traditional knowledge which was widespread in the past. The present study also suggests for research and development of natural antibacterial compounds that are safe for the host or specific for oral pathogens. The active principles of these plants should be incorporated into modern healthcare practices for easier and cheaper oral health treatments. Thus, traditional knowledge should be integrated with modern dental care practices to formulate their sustainable utilization.

\section{ACKNOWLEDGEMENT}

Authors are grateful to Yenepoya University for permitting to carry out this study. Authors would like to thank the participants and the many health service providers who contributed for the study.

\section{REFERENCES}

1. Sheiham A. Oral health, general health and quality of life. Bulletin of the World Health Organization 2005;83(9):641-
720.

2. Almas K. The antimicrobial effects of extracts of Azadirachta indica(Neem)and Salvadora persica (Arak) chewing sticks. Indian Journal of Dental Research 1999;10(1):23-26.

3. Dakshina Kannada district at a glance. 2007-2008, Published by District Statistical Officer, D.K, Mangalore.

4. B Bhagya, KR Sridhar. Ethnobiology of coastal sand dune legumes of southwest coast of India. Indian Journal of Traditional Knowledge 2009;8(4):611-20.

5. Chopra RN, Chopra IC, Handa KL. Chopra's indigenous drugs of India. 2nd ed. Calcutta: UN Dhur and Sons; 1958.

6. Hebbar SS, Harsha VH, Shripathi V. Ethnomedicine of Dharwad district in Karnataka India. Plants used in oral health care. Journal of Ethnopharmacology 2004;94:261-66.

7. Bhasin V. Oral Health Behaviour Among Bhils of Rajasthan. Journal of Social Science 2004;8(1):1-5.

8. Saeki $Y$, Ito $Y$, Okuda K. Antimicrobial action of natural substances on oral bacteria. Bulletin of Tokyo Dental College 1989;30:129-35. 